Jaspal, R. (2014). Sexuality, migration and identity among gay Iranian migrants to the UK. In Y. Taylor \& R. Snowdon (eds.), Queering Religion, Religious Queers. London: Routledge.

\title{
Sexuality, Migration and Identity among Gay Iranian Migrants to the UK
}

\author{
Rusi Jaspal, PhD \\ De Montfort University
}

Homosexuality ${ }^{1}$ is strictly forbidden in the Islamic Republic of Iran. It is punishable by imprisonment, flogging and, under certain circumstances, it carries the death penalty. Although homosexuality has long been a social taboo in Iranian society, the Islamic Revolution of 1979 introduced draconian judicial measures against this 'social ill'. There are thousands of non-heterosexual ${ }^{2}$ people currently living in Iran - many of them remain socially invisible' to avoid persecution. The immense social stigma of homosexuality and danger of state-sponsored persecution, on the one hand, and the desire to 'live out' one's sexual identity, on the other, can potentially induce social and psychological dissonance with negative outcomes for well-being (Jaspal and Cinnirella, 2010). Many non-heterosexual Iranians seek ways out of Iran in pursuit of greater social and sexual freedom. For example, some individuals have utilised educational and vocational opportunities in the West in order to leave Iran - this has allowed exposure to different ways of thinking about their sexualities. Often migrants are joining sizeable Iranian communities around the world: for instance, there are over 120,000 Iranians living in Canada and some 70,000 Iranians currently living in the UK. ${ }^{3}$ Migration can offer important opportunities for, and changes in, sexual identity development, as well as continued involvement in the Iranian ethno-national community.

Scholars have attempted to understand and explain homophobia in the Islamic Republic. Accordingly, there has been some scholarly engagement with gender and sexuality (Gerami, 2003; Najmabadi, 2013), and homosexuality in the Islamic Republic (Afary, 2009; Najmabadi, 2005). Yet, this theoretical work has not been matched by empirical

\footnotetext{
${ }^{1}$ The socio-legal and medicalised term 'homosexuality' is used here in accordance with the Iranian government's position which dichotomises sexual behaviour (heterosexual versus homosexual).

${ }^{2}$ In this chapter, the term "non-heterosexual" is used because it embraces the plethora of sexual identity labels that individuals tend to use in contrast to 'heterosexual'.

${ }^{3}$ Statistics Canada: http://ukforiranians.fco.gov.uk/en/window-to-britain/cultural/iranians-inuk/; UK Foreign and Commonwealth Office http://ukforiranians.fco.gov.uk/en/window-tobritain/cultural/iranians-in-uk/
} 
investigations of the identities and experiences of non-heterosexual Iranians, and there has been no insight into how migration to a 'safe' country, such as the UK or Canada, can impact

identity. This chapter provides some preliminary insight into the identities and experiences of a group of gay ${ }^{4}$ Iranian migrants to the UK, with a focus on perceived changes in identity since migration. Moreover, the study explores how individuals understand and manage the dominant, and often conflicting, norms, values and representations regarding sexuality in the Iranian and UK contexts.

\section{Homosexuality in the Islamic Republic}

On 24 September 2007, Mahmoud Ahmadinejad, President of the Islamic Republic of Iran, gave a speech at Columbia University in New York. During the question and answer session that followed it, a member of the audience asked, 'Iranian women are now denied basic human rights and your government has imposed draconian punishments including execution on Iranian citizens who are homosexuals. Why are you doing those things?' To which Ahmadinejad responded, 'We don't have homosexuals, like in your country. I don't know who told you that'. This statement elicited laughter and booing from the audience, but it reflected the Iranian stance on homosexuality: homosexuality is not publicly acknowledged and a 'gay identity' exists only in the West (Islam, 1998).

According to Iranian law, which is modelled on Islamic Sharia law, homosexuality is illegal. Indeed, Islamic holy scripture (the Koran), Islamic law (Shari'ah), and the verbal teachings of the Prophet Mohammed (Ahadith), collectively, appear to outlaw homosexuality (Duran, 1993). Iranian law regards homosexual acts as a serious crime and metes out severe punishments to offenders. For instance, it dictates that two unrelated men lying under the same bed cover will be punished with 60 lashes; that homosexual relations without anal penetration carries a penalty of 100 lashes; and that anal intercourse will be punished with death by hanging (Parnian, 2006).

After China, the Islamic Republic of Iran performs more executions than any other country in the world. It is unclear how many non-heterosexual individuals have been executed since the Islamic Revolution in 1979, but between 1979 and 1990 some 107

\footnotetext{
${ }^{4}$ This study acknowledges sexual diversity in Iran but focuses on the identities and experiences of gay men, in particular. There is no attempt to generalise the results of the study of gay men to the wider non-heterosexual population in Iran. However, in order to contextualise the study and its findings, there is some general discussion of non-heterosexual Iranians throughout the chapter.
} 
executions were recorded. ${ }^{5}$ There has been international outrage at the Islamic Republic's draconian judicial measures against homosexuals, which seems to have led the Iranian government to conflate homosexuality charges with other highly stigmatised crimes such as rape, pedophilia and espionage. This has served to distract the general public from the charge of homosexuality, to re-focus attention on the other morally offensive charges and to attenuate public sympathy for the accused (Afary, 2009).

Individuals can be convicted of homosexuality only if they confess four times or if four righteous Muslim men testify that they have witnessed a homosexual act (Parnian, 2006). Prima facie, it can appear as if the law exists in theory rather than in practice given the difficulty of 'proving' homosexuality. However, the law has been, and continues to be, applied, sometimes through forced confessions (Afary, 2009). The existence of these homophobic laws has ensured that homosexuality remains in the private sphere and, as highlighted by Ahmadinejad's remarks at Columbia University, that it remains silenced in the public sphere (Roscoe and Murray, 1997).

Why is the Islamic Republic so averse to homosexuality? In accordance with dominant religious and cultural ideology in Iran, gender norms are supposed to map neatly onto biological sex. Thus, men and women are expected to manifest particular norms, values, behaviours and responsibilities, and this is legally regulated (Najmabadi, 2005). However, homosexuality transgresses dominant gender and sexual norms in the Islamic Republic. It contradicts the prevalent norms that sexual intercourse constitutes a sacred union between $a$ man and a woman; that it should take place within marriage; and that Muslim families have a responsibility to procreate (Duran, 1993). In public thinking, homosexuality is anchored to stigmatised sexual perversions, such as pederasty, pedophilia, and rape (Shahidian, 1999) and is, thus, widely regarded as 'immoral, an illness, a sin, a crime and abnormal' (Parnian, 2006, p.351). Consequently, non-heterosexual Iranians may find it difficult to construct an identity around their sexuality.

Despite its stance on homosexuality, the Iranian government facilitates sex change operations for transsexuals. In fact, after Thailand, the Islamic Republic of Iran performs more sex change operations per annum than any other country in the world (Najmabadi, 2013). Despite the strict prohibition of homosexuality, transsexuality was declared to be legal in a fatwa (religious ruling) by Ayatollah Khomeini in the 1980s. It was declared that, as a

\footnotetext{
${ }^{5}$ See The Boroumand Foundation for Human Rights in Iran website. http://www.iranrights.org/english/memorialsearch.php?do_search $=$ Search\&charges $=1778515990 \&$ pagenum $=0$
} 
solution to gender identity disorder, sex assignment surgery could be performed under governmental supervision. However, the Islamic Republic's stance on transsexuality should not obscure its deeply homophobic stance: the government makes a very clear distinction between transsexuality (which they view as a 'sickness') and homosexuality (which they regard as 'deviant') (Afary, 2009). The encouragement of transsexuality may in fact constitute a means of 'restoring' and maintaining dominant gender and sex norms in Iranian society, implicitly encouraging homosexuals to consider changing their sex to 'fit the paradigm'.

\section{Social resources for non-heterosexual Iranian men}

Various clandestine sexuality-related networks and resources have become available to nonheterosexual Iranian men, despite their legal status. A gay subculture has emerged in Tehran, particularly within the city's educated and cosmopolitan population - many non-heterosexual Iranian men regularly use Internet chat rooms, meet at house parties, and have appropriated public 'spaces' for socialising (Afary, 2009). This subculture has the potential to provide individuals with feelings of acceptance, belonging and self-esteem on the basis of their sexual identity.

The LGBT human rights movement in Iran has been led by Iranian-born Arsham Parsi. In 2001 he founded an Internet group called Rangin Kaman (Rainbow Group) which later became the Persian Gay and Lesbian Organisation in 2004. The group provided a virtual space in which non-heterosexual Iranians all over the country could openly discuss sexualityrelated issues. Furthermore, in the mid-2000s, MAHA: The First GLBT e-Magazine was published in Iran for the first time (Afary, 2009). The online magazine featured interviews with non-heterosexual activists, and published articles and letters on the social, psychological and emotional difficulties experienced by individuals as a result of being closeted. It invited a positive re-definition and re-evaluation of what it meant to be non-heterosexual, and attempted to 'normalise' gay identity. The magazine was also critical of religious thinkers in Iran and the Iranian government in particular, and attempted to advocate a more tolerant reading of the Quran (see also Yip, 2005).

These strides in improving the lives of non-heterosexual Iranians were curtailed by the forced closure of the e-magazine in 2006 and Parsi's departure from Iran in 2005. Pursued by the Iranian authorities, Parsi escaped to Turkey and later settled in Toronto, Canada. However, he remained active in his campaign: in 2008 he founded The Iranian Railroad for 
Queer Refugees (IRQR), which has its headquarters in Toronto, Canada and branches in the US, Europe and an underground office in the Islamic Republic of Iran. The organisation facilitates the departure of non-heterosexual Iranian refugees from Iran and assists them in asylum applications, housing and financial support. Moreover, it functions as a pressure group in support of LGBT rights, and has successfully campaigned to prevent the deportation of non-heterosexual refugees back to the Islamic Republic of Iran, where individuals may face severe penalties, including death. There is anecdotal evidence that refugees experience greater social and psychological well-being upon settlement in non-heterosexual affirmative countries. ${ }^{6}$ There remains a need to examine systematically the accounts of non-heterosexual Iranian migrants.

\section{THEORY AND METHOD}

\section{Participants}

This chapter examines the social and psychological experiences of 25 self-identified Iranian gay men. Participants were aged between 20 and 29 years (mean: 24.2 years). All of the men were resident in the UK at the time of interview and were Iranian migrants rather than visitors or temporary students. There were 15 participants who had entered the UK on a student visa and were enrolled at higher education institutes; six men were seeking asylum in the UK (due to political and/ or sexuality-related issues); and four individuals had entered the UK with work permits. Although there was some variation in participants' reasons for residing in the UK, they all expressed a desire to remain in the UK in the long-term and had submitted, or were planning, applications for permanent residency. Whilst all participants expressed a sense of national attachment to Iran, none of them wished to live in the country, citing the risk of persecution on the basis of sexual orientation. All participants described themselves as having a Shiite Muslim 'background'. Among participants, twelve described themselves as 'practising Muslims', six as 'culturally Muslim' and seven participants categorically rejected any affiliation (either spiritual or cultural) to Islam. Two of these seven participants highlighted their curiosity to learn more about the Christian faith.

A snowball sampling strategy was employed and initial participants were recruited from within the researcher's personal networks. It is noteworthy that only three individuals in

\footnotetext{
${ }^{6}$ Iranian Railroad for Queer Refugees Website http://english.irqr.net/2012/12/06/iranian-homosexual-storydeath-execution-iranian-gay-in-canada/
} 
the sample reported having disclosed their sexual identity to friends and family: these experiences were generally negative and had reportedly caused some family adversity. Thus, some participants were understandably nervous about disclosing their experiences to the interviewer, whom they did not know personally, until a sense of trust had been established. The snowball sampling strategy helped to transmit the trust established between previous participants to prospective participants.

The interviews were guided by a semi-structured interview schedule consisting of 20 exploratory, open-ended questions regarding sexuality, migration and identity. Interviews lasted between 60 and 120 minutes. 10 interviews were digitally recorded and transcribed verbatim. However, in accordance with participants' wishes, 15 interviews were not recorded. In these cases, the interviewer made very detailed notes during and after the interviews, which were later compiled and shown to the participant who was able to comment on their accuracy in reflecting the content of the interview. This research was conducted in accordance with British Psychological Society ethical guidelines. ${ }^{7}$ Pseudonyms are used in this chapter to protect participant anonymity.

\section{Analytical and theoretical approach}

The interview transcripts were analysed using Interpretative Phenomenological Analysis (Smith and Osborn, 2008), which is a qualitative analytical technique that aims to capture participants' attempts to make sense of their experiences. The approach conceptualises the participant as a 'cognitive, linguistic, affective and physical being,' and assumes a relationship between verbal reports and the cognitions and emotions with which they are concerned (Smith and Osborn, 2008, p.54). The method focuses upon the meanings that particular lived experiences hold for the individual and its idiographic mode of enquiry facilitates in-depth exploration of each individual's account.

The analysis was informed by Identity Process Theory from social psychology, which explains how individuals construct and manage identity (Breakwell, 1986). The theory has been fruitfully applied to previous empirical studies of sexuality, religion and ethnicity (see Jaspal, 2012 for an overview). According to Identity Process Theory, the content of identity consists of the characteristics that, taken as a constellation of identity elements, mark the individual as unique and distinctive. Breakwell (1986) makes two important points about

\footnotetext{
${ }^{7}$ British Psychological Society Code of Ethics and Conduct http://www.bps.org.uk/system/files/documents/code_of_ethics_and_conduct.pdf
} 
identity content. First, she argues that elements of identity (e.g. group memberships, traits) differ in their degree of centrality and their hierarchical arrangement. Second, each identity element (e.g. being gay; being an Iranian) is appended a specific positive or negative value, but these values can change in accordance with social context. Identity Process Theory posits that, while identity resides in psychological processes, it is manifested through thought, action and affect. These manifestations of identity can be captured in in-depth qualitative interview studies (Coyle and Murtagh, 2013).

I transcribed the recordings, read the transcripts closely, and noted preliminary interpretations in the left margin. At the next step, the right margin was used to collate these initial codes into potential themes which captured the essential qualities of the accounts and shed light on the phenomenological worlds of participants. The analyst reviewed the list of themes rigorously against the data in order to ensure their compatibility and listed numerous interview extracts against each corresponding theme. At this stage, the analyst selected specific interview extracts, which were considered vivid, compelling and representative of the themes for presentation in this chapter. Finally, the following three superordinate themes were developed and ordered into a logical and coherent narrative structure: (i) Being gay in Iran: A social and psychological struggle; (ii) Capitalising on being gay in Iran; and (iii) Migration: A psychological 'cue' for re-conceptualisation. These themes are discussed in the next section, because they shed light upon the identities and experiences of the gay Iranian migrants who participated in the study.

\section{ANALYSIS}

\section{Being gay in Iran: A social and psychological struggle}

Participants were encouraged to reflect upon their experiences of being gay in Iran and the implications for their identities. There was a clear sense of struggle in individuals' accounts:

It was always a struggle for me. I do love Iran, it's my country where I was born and where I lived with my parents, my friends, my people but in Iran I was sad. I was sad because I could not be who I am. I didn't have an identity. It was like living like a stranger. (Hamid, 25) 
In Hamid's account, being gay in Iran is referred to as a 'struggle,' due partly to the dilemma of perceiving an attachment to his homeland, on the one hand, and to the recognition that his fellow countrymen do not allow him to manifest his gay identity. Like Hamid, several participants associated Iran with parents, friends, acquaintances, and other valued personal relationships, but lamented that these networks were unwilling to accept an important element of their identity, namely their sexuality. In addition to feelings of sorrow, this could lead to severe confusion regarding one's sense of self:

It came to a point where I'd look at myself in the mirror and not really know who that guy was looking back at me. It looked like a straight guy to me and to everyone else but I knew that inside I was gay, a woman basically, but it was always a man in the mirror. (Mohammad, 23)

Both Hamid and Mohammad point to the transient sense of depersonalisation (Rosenberg, 1987) that can arise from being gay in the generally homophobic context of Iran. Hamid indicated a loss of his sense of identity and argued that he was therefore 'living like a stranger.' This perceived loss of identity had negative emotional outcomes, such as the inability to be 'who I am' inducing feelings of sadness. Similarly, Mohammad compellingly exhibited his perceived loss of identity by describing his experience of looking at himself in the mirror but not recognising his reflection as his own. For Mohammad, this metaphorical description elucidated his experience of depersonalisation - the perceived disjuncture between his appearance as a masculine man but his self-perception as a feminine gay man ('a woman basically') was deeply disturbing for him at a psychological level. This may be attributed to the heteronormative understanding of gender and sex roles in Iran, whereby sexually the male is the active partner and the female is the passive partner (Afary, 2009). Accordingly, the policy of compulsory heterosexuality means that in Iran a sexually passive male is not socially regarded as a man but rather as a woman (Roscoe and Murray, 1997), a representation internalised by Mohammad.

Heteronormativity and compulsory heterosexuality were clear sources of psychological tension for participants thinking about their sexual identity. In several accounts, religion surfaced as a key factor in their meaning-making vis-à-vis their sexual 
identities particularly during their time in Iran. This was unsurprising given the ubiquity of religious imagery and representation in the Islamic Republic (Kazemipur and Rezaei, 2003).

Islam in Iran, it's everywhere. You can't get away from it [...] Like the religion thing, each time Islam mentions it's an abomination or whatever, it caused me depression. I didn't know what I was living for or where I'm going in my life. Am I Muslim or not? I wanted to take my life. I was thinking 'when I go in the army with men, away from my family, it will be the end of me, for a gay person'[...] The religion thing would be worse there (Sohail, 26)

Like Sohail, several participants highlighted the ubiquity of Islam in Iran, which indicated that religion constituted an important social and psychological lens for viewing sexualityrelated issues (Jaspal and Cinnirella, 2010). This was invoked as a cause for anxiety, depression and, as evidenced by the accounts of Hamid and Mohammad, depersonalisation. Sohail remarked that the ubiquity of Islam in Iran was disturbing due to its constant denigration and demonisation of homosexuality. This led several participants to question the authenticity of their Muslim identity (Jaspal, under review), which could jeopardise individuals' sense of self due to the centrality of Islam to Iranian identity.

An important theme in individuals' accounts of being gay in Iran concerned the mandatory military service for most men aged 18 and over. Participants expressed concerns regarding military service - the army was seen as a context in which the 'religion thing would be worse.' Sohail argued that the religiously-derived social stigma of homosexuality would be particularly potent within this context. A more specific concern was that being in the company of men (due to sexual desire) and estrangement from his family (a source of moral support) would cause further anxiety.

The immense social stigma appended to homosexuality in Iranian society, coupled with doubts surrounding the authenticity of one's Muslim identity, led some individuals, like Sohail, to contemplate suicide:

In Iran you see on the news and in the newspapers that a gay person has been executed because in Iran it is against Shariah and in Iran, in Islam, if you are gay you are a criminal [...] Islam has messed Iran up. 
I mean, if you live your life as you wish, you are a criminal. So I thought 'what's the point in living if I can be killed one day if I live my life, I mean, really live' (Ashkan, 25)

For Ashkan, compulsory heterosexuality was powerfully evidenced by the status of homosexuality as a capital crime in Iran and the actual executions of gay people reported in the Iranian press. Ashkan attributed this to the rise and dominance of Islam in Iran. For instance, he notes that gay people face execution 'because in Iran it is against Shariah' and argues that Islam has actively 'messed Iran up'. This serves to construct Islam as the root cause of homophobia, which in turn seems to induce a negative evaluation of Islam. This is consistent with research into external attribution, whereby individuals attribute negative aspects of their lives and experiences to external stimuli in order to enhance meaning and to make sense of negativity and adversity (Kelley and Michela, 1980). The association of homosexuality and the death penalty in individuals' minds seemed to lead them to be fearful for their lives and the future and, in some cases, this could feed into individuals' suicidal thoughts. Indeed, Ashkan reported having questioned the merits of living a lie, whilst also living in constant fear for his life. Yet, being gay was regarded by some individuals as providing positive opportunities.

\section{Capitalising on being gay in Iran}

Most participants expressed dismay at the prospect, or actual experience, of having to perform mandatory military service. Military service was regarded as a highly masculine job, entailing engagement with 'masculine activities' (e.g. intense physical exercise).

Furthermore, there was a fear of encountering 'hyper-masculinity' among other conscripts given that many were likely to be 'typical Iranian guys.' Indeed, Khosravi (2009, p.593) has noted that the military is 'associated with manhood and manly duties' and that, according to popular belief, it is what 'makes one a man.'

Although several participants in the study had completed their mandatory military service, others had managed to evade it by leaving the country or by applying for exemption due to special circumstances. Two individuals in the sample, Pouya and Ahmad, made strategic use of their sexual and religious identities in order to evade military service: 
I was worrying a lot about the army because I just couldn't do it or imagine it [...] So I just told the army doctor that I'm gay and I can't control my feelings. I told him in Islam there's forgiveness and God made me how I am. I don't want to be gay so I can't be in the army [...] He was really nice to me actually. He spoke to me like I'm ill, like there's a problem with me and that was OK because at the time I also thought there's something wrong with me [...] I was discharged from the army because I'm gay. (Pouya, 23)

Pouya reported disclosing his sexual orientation to the army doctor in order to seek exemption from military service. There were three important aspects of his sexual selfdisclosure. First, he acknowledged his lack of self-efficacy in relation to his sexual orientation by arguing that he had no control over his feelings. Second, he strategically invoked the Islamic tenets of forgiveness and human beings as God's creation (El Azayem and Hedayat-Diba, 1994). Third, and perhaps most importantly, Pouya noted that he did not wish to be gay but that an all-male environment such as the army could cause him to 'become' gay (that is, to engage in homosexual acts). This implicitly constituted a 'warning' against sending him to the army, which paved the way for a more accepting and sympathetic response from the army doctor who proceeded to dismiss Pouya, rather unproblematically, from his military duties.

I told my mother because I couldn't take it anymore and she said I'm ill. I can laugh now but I didn't then [...] I didn't go to the army. It was like I needed to be cured of a disease so I didn't have to. I was so happy (Ahmad, 27)

Both Pouya and Ahmad were able to capitalise on their sexual orientation in order to evade military service due to the 'medicalisation' of homosexuality in Iranian social discourse (Afary, 2009). This was clearly evidenced in Pouya's account of being spoken to 'like a patient' and in Ahmad's perception that he was treated as if he 'needed to be cured of a disease.' Crucially, the medicalisation of homosexuality in Iranian society is so potent that even Pouya himself was convinced that 'there's something wrong with me.' In short, despite the clear obstacles that being gay in Iran can place in one's life journey and the negative 
social and psychological outcomes of being gay in Iran, these accounts show that some individuals may be able to capitalise on both their sexual and religious identities in order to live their lives in a psychologically satisfying way. Indeed, for most participants, the avoidance of military service was just one part of leading a psychologically satisfying life.

\section{Migration: A psychological 'cue' for re-conceptualisation}

For many individuals, migration constituted a major turning-point in their lives since it provided a psychological 'cue' for re-conceptualising problematic and threatening aspects of their identities. Some participants were empowered to re-negotiate their relationship with their religious identity, which was seen as contradicting their sexual identity. Complete disidentification with Islam made some individuals feel liberated from what they described as the 'shackles' of Islam:

I left Islam, I mean, properly left the shackles of Islam when Islam rejected me. It rejects gay people so I rejected it [...] When I came to England I could say it openly without any fear, even to Iranians. (Majid, 27)

I like filling out forms because I can just put 'Atheist' in the religion box. There is a box that says that and I feel that it reflects my position well. Sometimes I want to just put in 'gay' where it says religion to show Muslims what I think of Islam. (Ashkan, 25)

Several respondents seemed to prioritise their sexual identity and to view religion as an unnecessary obstacle to sexual self-actualisation (Jaspal and Cinnirella, 2010). Although Majid reported having lost faith in Islam long before his arrival in the UK, due to his perception that Islam had 'rejected' him, he did not publicly acknowledge his departure from the religion until migration. This was attributed to fear of persecution and prosecution in Iran, since apostasy is a capital crime in the Islamic Republic of Iran (Zimmermans, 2009). Conversely, migration to the UK enabled Majid to manifest openly his disidentification with Islam without fear. This meant that Islam could no longer pose obstacles for sexual selfactualisation. 
Similarly, Ashkan illustrated his sense of triumph over Islam, which he inculpated for the discrimination and psychological conflict he had experienced. He clearly delineated himself from 'Muslims,' whom he positioned as an outgroup. His poignant sense of bitterness towards Islam was illustrated by his desire to 'show Muslims what I think of Islam.' This is consistent with the observation that gay individuals of faith may reject their religious identity in favour of their sexual identity (Yip, 2005). This may be particularly potent when religion is in fact perceived as a threatening entity that justifies persecution and capital punishment.

In addition to re-negotiating their relationship with religious identity, participants reported a change in sexual self-categorisation subsequent to migration. Hamid more readily laid claim to a gay identity:

Here it suddenly felt OK to call myself gay and when my friends said things that implied I'm gay or we're gay, it started to feel fine. In Iran I always considered myself to be a straight guy, seriously, I'm not kidding [...] At the peak, I mean at my most open moment, I saw myself as bi but that was it. Never ever, ever did I think I'd be gay. (Hamid, 25)

It has been observed that being gay may be conceptualised in terms of a (sexual) behaviour, rather than as an element of identity (Jaspal and Cinnirella, 2010). Similarly, there is evidence that in Middle Eastern cultures gay identity may be completely resisted while homosexual behaviour may be silently tolerated, though never publicly acknowledged (Roscoe and Murray, 1997). Accordingly, Hamid reported initially viewing himself as straight, which is not unusual for individuals who take the sexually active role or 'man's role' (Khosravi, 2009; Najmabadi, 2005), and then later as gay. Migration to a gay affirmative context, such as the UK, may facilitate self-categorisation as gay and public acknowledgement of gay identity, enabling individuals to 'live out' their sexuality Participants' modes of 'living out' their gay identity seemed to change significantly upon migration to the UK. In Iran, this consisted of discreetly, though defiantly, socialising with other gay people:

We just used to move around each other's houses, having parties with just gay guys coming around, listening to music together, eating, 
drinking and having sex. It was a good place to meet guys. It was the only safe way [...] It felt like I was beating the regime, you know (Ali, 24)

Every Friday we went to Jaam-e Jam [a food court in Tehran] and it's like a safe place in a way, for meeting guys, but that was it really [...] In a way it just felt like I was being myself when I was there, with my friends. At the end there wasn't any fear because it had become our territory, not the Basij's (Abbas, 25)

The social and collective element of gay identity was important for participants during their time in Iran. Meeting and socialising with other men was a priority for both Ali and Abbas there seemed to be a desire to construct a social group identity around sexuality (Jaspal and Cinnirella, 2010). Moreover, Abbas highlighted the importance of appropriating a 'gay space,' which for several respondents was Jaam-e Jam, a food court in North Tehran. This was a 'safe' space in which individuals could 'live out' their gay identity in a socially and psychologically satisfying manner - by socialising with others and 'being oneself' without fear.

By 'living out' their gay identity, several interviewees felt that they were defying the Iranian regime which strictly prohibits homosexuality (Mahdavi, 2007). For Ali, socialising with other gay people at house parties and engaging in casual sex were viewed as means of 'beating the regime,' while, for Ali, appropriation of the food court space ('our territory') constituted a victory over the Basij, an institution associated with the Iranian regime (Mahdavi, 2007). Thus, defiance of the homophobic authorities seemed to constitute an important dimension of being gay.

Migration to the UK engendered a turning point in manifestations of gay identity. Individuals no longer perceived the need to be defiant. Being gay in the UK now meant that they could adopt a less politicised stance on their sexual self-actualisation. This included looking for casual sex for sexual, rather than political, fulfilment (Mahdavi, 2007): 
Now in England I just love the feeling of thinking 'I want sex' or I want to meet a guy and you log onto Grindr ${ }^{8}$ or Gaydar $^{9}$ or some other website. There's no fear of a Basiji being behind a profile. You know it's genuine [...] The freedom is overwhelming (Sohail, 26)

Since coming to London it feels like I've got to do all the stuff I couldn't do in Iran [...] I think I've gone a bit mad on the gay scene. And I just love telling people about what I do, I just love it. My straight friends do give me looks sometimes. (Pouya, 23)

Several respondents celebrated the 'freedom' available to them in the UK context, which they contrasted with the perceived lack of freedom in Iran. Sohail exemplified this by invoking the availability of casual sex on the Internet in the UK (using the smartphone app, Grindr, and the Internet website, Gaydar). It is noteworthy that the Internet in Iran is heavily restricted; sites that are deemed by the Iranian government to be 'immoral' or 'un-Islamic' cannot be legally accessed by Internet users (Rahimi, 2003; The Guardian, 23 April 2013). Although there are ways of accessing illegal sites (e.g. by using US proxy servers), as Sohail highlighted, there are perceived risks associated with the use of gay dating sites. In the past, individuals have been lured into traps, set up by members of the Basij or morality police, under the pretext of casual sex or other illegal activities (Afary, 2009; Mahdavi, 2007). For Sohail and other participants, freedom is defined as the ability to manifest their sexuality without fear of prosecution.

Like Pouya, several participants reported having 'gone a bit mad' upon migration to the UK due to this enhanced sense of freedom. For Pouya, this meant doing things that he was unable to do in Iran. Moreover, there was a clear desire for individuals to celebrate their 'subversive' experiences in the UK and to share these experiences with others. Pouya and other participants acknowledged that this 'excessively' open stance on sexuality-related issues could cause some embarrassment among heterosexual friends, in particular, but this enabled them to 'live out' their gay identity in ways that were hitherto unavailable to them.

\footnotetext{
${ }^{8}$ Grindr is a social networking application for non-heterosexual men. It functions on smartphone devices and allows individuals to locate and communicate with other users in close proximity.

${ }^{9}$ Gaydar is an internet-based social networking website for non-heterosexual men. Users create individual profiles in which they can indicate information about themselves and their ideal partners.
} 
This openness regarding sexuality stood in stark contrast to the norm of 'silencing' gay identity in the Iranian context (Parnian, 2006), giving rise to a novel means of sexual selfactualisation.

\section{CONCLUSION}

This chapter provides some insight into the social and psychological struggles and the changes in identity and experience among gay Iranian migrants to the UK. The study shows how individuals' perspectives can be influenced by their migratory experience, which in many cases provides a new lens for viewing and evaluating homosexuality (Cantu, 2009).

Individuals' reported struggles can be attributed to the pervasive stigma of homosexuality in Iran, which constructs gay identity as a negative element of the self and as something to be silenced and denied rather than embraced and celebrated (Parnian, 2006). What can be particularly traumatic is the status of homosexuality as a capital crime in Iran. Individuals were acutely aware of the high-profile executions of allegedly homosexual people, which seemed to confirm their belief that they would be persecuted for being gay. Understandably, this induced negative emotional experiences such as fear and anxiety, and other negative social and psychological outcomes.

In trying to make sense of their social positions, several participants attributed the stigma of homosexuality to the rise of Islam in Iranian society, which could in turn lead to negative evaluation of the religion and, in some cases, to total disidentification with Islam (Warraq, 2003). Given the Islamic basis of the Iranian political system and the centrality of Shariah in the Islamic justice system, individuals may be inclined to identify Islam as the 'root cause' of social ills for which the Iranian government is responsible. Participants with only weak levels of religious identification manifested a tendency to disidentify with Islam. Conversely, for individuals with stronger levels of religious identification, their sexual orientation could induce doubts surrounding their authenticity of their Muslim identity (Jaspal, under review) and, thus, their position within Iranian society. This proved to be psychologically threatening and could lead to feelings of anxiety, depersonalisation, and even suicidal thoughts.

Yet, gay Iranians may be able to re-construe their social circumstances and to make strategic use of their sexual and religious identities in order to live their lives in socially and psychologically satisfying ways. Two participants pointed to the advantages of the pervasive 'medicalisation' of homosexuality in terms of avoiding military service in Iran. However, one 
negative outcome of such 'medicalisation' was that some individuals themselves came to perceive their gay identity in negative terms as an abnormality or as a marker of their femininity (Afary, 2009). Similarly, some participants reported making strategic use of their religious identity in order to elicit more positive and lenient responses to the disclosure of their sexual orientation - the Islamic tenet of forgiveness and human beings as God's 'creation' were invoked.

Migration to the UK provided most participants with a very different perspective on their sexual and religious identities, and with the means of re-conceptualising problematic elements of their identities and experiences (Khosravi, 2009; Shahidian, 1999). Migration enabled those individuals who manifested a weak religious identity and who felt that Islam had, in some way, let them down, to formalise their departure from the Islamic faith and to declare this publicly. This was no longer viewed as apostasy (a capital crime in the Islamic Republic of Iran), but rather as an individual choice (Warraq, 2003). Furthermore, migration seemed to facilitate a stronger sense of gay identity among participants, many of whom reported initially denying their gay identity or as viewing it as a negative element of the self. This may be attributed to the availability of positive representations of homosexuality in gay affirmative contexts.

When two identities are in conflict at a psychological level, individuals are inclined to choose between one of them (Jaspal and Cinnirella, 2010). Migration seemed to provide individuals with such a choice, and most individuals were more inclined to prioritise their sexual identity over their religious identity (cf. Shahidian, 1999). In the UK context participants did not feel compelled to manifest their religious identity, unlike in Iran where Islamic religious imagery is ubiquitous and religious participation is socially and legally expected (e.g. collective prayers at school) (Kazemipur and Rezaei, 2003). Moreover, migration to the UK enabled individuals to 'live out' their gay identity in a less politicised manner (cf. Mahdavi, 2007). For instance, participants celebrated the ease with which they could meet and socialise with other gay men without fear of persecution. Crucially, for most respondents, gay identity became something to be proud of, as evidenced by their reported willingness to disclose their socio-sexual experiences to others, including heterosexual friends.

This chapter shows the resolve and determination of gay Iranians to 'live out' their gay identities, despite the massive obstacles they can face in doing so within the national context of Iran. They make strategic use of their identities and social contexts in order to 
meet their sexual identity needs. Sexual identification can symbolise resistance against the Iranian regime (Mahdavi, 2007). The chapter also shows their resilience because despite negative social and psychological experiences in Iran, migration seemed to empower individuals to 'live out' their gay identities. Individuals' thinking seemed to have changed for the better - they now felt more able to accommodate and defend their gay identities.

On the basis of this chapter and existing work in this area, there seems to be a need to engage critically with at least two issues. The first issue concerns how the international community responds to extreme homophobia in the Islamic Republic of Iran. Iran is one of a handful of countries in which homosexuality is punishable by death - its treatment of nonheterosexual individuals is appalling. It is hoped that the protection of LGB rights will feature prominently on the agenda of the international community. The second issue concerns asylum cases for non-heterosexual Iranians (in the UK and other 'safe' countries). These cases should be given the attention and seriousness that they clearly deserve - nonheterosexual individuals face dangers in the Islamic Republic of Iran simply because of who they are. This chapter elucidates just some of the immense social and psychological improvements that can be observed among individuals who manage to leave Iran and enter societies that are more accepting of sexual diversity.

In contrast to the parochial claims of President Ahmadinejad regarding the absence of homosexuals in Iran, there are in fact thousands of non-heterosexual people living in the Islamic Republic of Iran. Many of them are 'living out' their identities to the best of their ability, and some are desperately seeking a way out of Iran. Most of the accounts in this chapter would resonate among these people, but there are many other stories yet to be recounted. It is hoped that this chapter will stimulate further research in this area and that researchers will continue to make the voices of non-heterosexual Iranians heard.

\section{REFERENCES}

\section{Books and articles}

Afary, J. (2009) Sexual politics in Modern Iran. Cambridge: Cambridge University Press.

Breakwell, G.M. (1986) Coping with threatened identities. London: Methuen.

Britt, L. and Heise, D.R. (2000) 'From shame to pride in identity politics', in: S. Stryker, T.J. Owens and R.W White, eds. Self, identity and social movements. Minneapolis: University of Minnesota Press, pp.252-268.

Cantu, L. (2009) The sexuality of migration. New York: New York University Press. 
Coyle, A. and Murtagh, N. (2013) 'Qualitative approaches to research using identity process theory', in: R. Jaspal and G.M. Breakwell, eds. Identity process theory: Identity, social change and social action. Cambridge: Cambridge University Press.

Duran, K. (1993) 'Homosexuality in Islam'. In: A. Swidler, ed. Homosexuality and world religions. Harrisburg, PA: Trinity Press International, pp.181-98.

El Azayem, G.A. and Hedayat-Diba, Z. (1994) 'The psychological aspects of Islam: Basic principles of Islam and their psychological corollary', International Journal for the Psychology of Religion: 4:41-50.

Gerami, S. (2003) 'Mullahs, martyrs, and men: Conceptualizing masculinity in the Islamic Republic of Iran', Men and Masculinities: 5:257-274.

Islam, N. (1998) 'Naming desire, shaping identity: Tracing the experiences of Indian lesbians in the United States', in: S.D. Dasgupta, ed. A patchwork shawl: Chronicles of South Asian women in America. Piscataway, NJ: Rutgers University Press, pp.72-96.

Jaspal, R. (2012) 'Coping with religious and cultural homophobia: emotion and narratives of identity threat from British Muslim gay men’, in: P. Nynäs and A.K.T. Yip, eds. Religion, gender and sexuality in everyday life. Farnham: Ashgate, pp.71-90.

Jaspal, R. (under review) Hyper-affiliation to the religious ingroup among British Pakistani Muslim Gay Men.

Jaspal, R. and Cinnirella, M. (2010) 'Coping with potentially incompatible identities: Accounts of religious, ethnic and sexual identities from British Pakistani men who identify as Muslim and gay', British Journal of Social Psychology: 49:849-870.

Kazemipur, A. and Rezaei, A. (2003) 'Religious life under theocracy: The case of Iran', Journal for the Scientific Study of Religion: 42:347-361.

Kelley, H.H. and Michela, J.L. (1980) 'Attribution theory and research', Annual Review of Psychology: 31:457-501.

Khosravi, S. (2009) 'Displaced masculinity: Gender and ethnicity among Iranian men in Sweden', Iranian Studies: 42:591-609.

Mahdavi, P. (2007) 'Passionate uprisings: Young people, sexuality and politics in postrevolutionary Iran', Culture, Health and Sexuality: 9:445-457.

Murray, S.O. (1997) 'The will not to know: Islamic accommodations of male homosexuality', in: S.O. Murray and W. Roscoe, eds. Islamic homosexualities: Culture, history and literature. New York: New York University Press, pp.14-54.

Najmabadi, A., ed. (2005) Women with moustaches and men without beards: Gender and sexual anxieties of Iranian modernity. Berkeley, CA: University of California Press. 
Najmabadi, A. (2013) Sex-in-Change: Configurations of gender and sexuality in contemporary Iran. Durham, NC: Duke University Press.

Parnian, H. (2006) 'The sexual rights of women and homosexuals in Iran', in: S. Seidman, N. Fischer and C. Meeks, eds. Handbook of the new sexuality studies. London: Routledge, pp.348-352.

Rahimi, B. (2003) 'Cyberdissent: The Internet in Revolutionary Iran', Middle East Review of International Affairs: 7:101-115.

Rosenberg, M. (1987) 'Depersonalisation: the loss of personal identity', in: T. Honess, and K. Yardley, eds. Self and identity: Perspectives across the lifespan. NewYork: Routledge and Kegan Paul, pp.193-206.

Shahidian, H. (1999) 'Gender and sexuality among immigrant Iranians in Canada', Sexualities: 2:189-222.

Smith, J. and Osborn, M. (2008) 'Interpretative phenomenological analysis', in: J. Smith, ed. Qualitative psychology: A practical guide to methods. London: Sage, pp.53-80.

Warraq, I., ed. (2003) Leaving Islam: Apostates speak out. Amherst, NY: Prometheus.

Yip, A.K.T. (2005) 'Queering religious texts: An exploration of British non-heterosexual Christians' and Muslims' strategy of constructing sexuality-affirming hermeneutics', Sociology: 39:47-65

Zimmermanns, T. (2009) 'Germany's asylum policy and Iran's new apostasy law', International Journal for Religious Freedom: 2:133-139.

\section{Newspapers}

The Guardian, 23 April 2013, Web censorship: The net is closing in, http://www .guardian.co.uk/technology/2013/apr/23/web-censorship-net-closing-in 